\title{
Bioactive Steroid and Triterpenoids from Bridelia stipularis (L) Blume
}

\author{
Adeeba Anjum ${ }^{1 \Psi}$, Md. Zakir Sultan ${ }^{2}$, Md. Al Amin Sikder ${ }^{1}$, Choudhury M. Hasan $^{1}$, \\ Muhammad Abdullah Al-Mansoor ${ }^{3}$ and Mohammad A. Rashid ${ }^{1}$
${ }^{2}$ Centre for Advanced Research in Science, University of Dhaka, Dhaka-1000, Bangladesh
${ }^{3}$ Bangladesh Council of Scientific and Industrial Research (BCSIR), Dr. Qudrat-I-Khuda Road, Dhanmondi, Dhaka-1215, Bangladesh \\ ${ }^{1}$ Department of Pharmaceutical Chemistry, Faculty of Pharmacy, University of Dhaka, Dhaka-1000, Bangladesh
}

(Received: November 03, 2016; Accepted: December 13, 2016; Published (web): December 27, 2016)

\begin{abstract}
Fractionation and purification of stem bark extract of Bridelia stipularis growing in Bangladesh afforded glut-5(6)-en-3-one (1), glut-5(6)-en-3 $\alpha$-ol (2), and (22E)-7-hydroxy-28-methylcholesta-4,22-dien-3-one (3). Compound $\mathbf{3}$ appears to be new, while compounds $\mathbf{1}$ and $\mathbf{2}$ have never been reported from this plant. The isolated compounds isolated exhibited cytotoxic activity against brine shrimp nauplii having significant $\mathrm{LC}_{50}$ and $\mathrm{LC}_{90}$ and moderate to strong antimicrobial activity against 13 Gram positive and Gram negative bacterial strains and 3 fungi. Here, compound 1 demonstrated highest inhibition of growth of microorganisms with zone of inhibition of $22.7 \mathrm{~mm}$ against Escherichia coli and compound $\mathbf{2}$ displayed zone of inhibition of $20.8 \mathrm{~mm}$ against Candida albicans. Compounds 1-2 also revealed moderate free radical scavenging activity in the DPPH method.
\end{abstract}

Key words: Bridelia stipularis, triterpenes, steroids, antimicrobial, cytotoxity, free radical scavenging

\section{INTRODUCTION}

Bridelia stipularis (L) Blume (Synonym: Clutia stipularis L., B. scandens, Local Bengali name: Pat Khowi, Family: Phyllanthaceae) is a climbing shrub, which grows in shady, moist forest floors. It is distributed in the forest areas of the central and eastern parts of Bangladesh. ${ }^{1}$ It is also found in India and Myanmar. The plant is used in the treatment of amoebic dysentery, chest pain, constipation, diarrhea, leucoderma and strangury. ${ }^{2}$ Decoction of bark is used for cough, fever and asthma. It has also shown hypotensive and hypoglycaemic actions in animal model, where the leaves are used for jaundice. ${ }^{3}$ As part of our continuing studies on Bridelia species growing in Bangladesh ${ }^{4,5}$ we attempted to isolate and identify the chemical constituents from the stem bark of B. stipularis and assayed for the biological activities of the isolated compounds.

Correspondence to: Mohammad A. Rashid

Tel.: +88-02-9661900-73, Extn.- 8137; Fax: +88-02-9667222;

E-mail: rashidma@du.ac.bd

${ }^{\psi}$ Present address: Department of Pharmacy, University of Rajshahi, Rajshahi-6205, Bangladesh

Dhaka Univ. J. Pharm. Sci. 15(2): 221-225, 2016 (December)

\section{MATERIALS AND METHODS}

General experimental procedures. Column chromatography was carried out on silica gel (70-230 mesh, E-Merck) and Sephadex LH-20 (20-100 $\mu \mathrm{m}$, Sigma-Aldrich Chemicals). Vacuum liquid chromatography (VLC) was conducted on silica gel (Kieselgel 60H). TLC and preparative-TLC (PTLC) were run on precoated silica gel plates Kieselgel 60 $\mathrm{F}_{254}$, Aluminum sheets, E-Merck, Germany). Melting points were measured on a hot stage melting point apparatus (PIC, India) and are uncorrected. ${ }^{1} \mathrm{H}$ NMR spectra were recorded on a Bruker $400 \mathrm{MHz}$ spectrometer and the chemical shifts are expressed in ppm with respect to residual non-deuterated solvent signal.

Plant materials. The stem bark of Bridelia stipularis (L) Blume was collected from the village of Panchouri, Khagrachhori District in February, 2007 and identified in Bangladesh National Herbarium, where voucher specimen has been deposited representing this collection (Accession No. DACB- 31378). 
Extraction and isolation. The air dried powdered stem bark of $B$. stipularis $(550 \mathrm{~g})$ was soaked in $1.5 \mathrm{~L}$ methanol for seven days and filtered through fresh cotton bed followed by Whatman number 1 filter paper. The filtrate was concentrated by using a rotary evaporator at $40{ }^{\circ} \mathrm{C}$. A portion of the methanolic crude extract (15 g) was subjected to VLC over silica gel (column length $14 \mathrm{~cm}$ and diameter $10 \mathrm{~cm}$ which was packed up to a height of 6 $\mathrm{cm}$ under reduced pressure). After loading the sample the column was eluted with petroleum ether, followed by mixtures of petroleum ether and ethyl acetate and finally with methanol to obtain 25 fractions of $100 \mathrm{ml}$ each. After TLC screening similar fractions (4 to $5 \mathrm{~A}$ ) were combined together and concentrated under reduced pressure. They were then subjected to preparative TLC using $n$-hexane-ethyl acetate (99:1) to yield compound 1 (8.5 $\mathrm{mg})$. Fractions $9 \mathrm{~A}$ to $11 \mathrm{~B}$ were also combined together and subjected to gel permeation chromatography over Sephadex LH-20, that eluted with $n$-hexanedichloromethane-methanol (2:5:1). Fifty five fractions were obtained and fractions with similar TLC feature were combined. Preparative TLC of fractions 20-26 over silica gel using toluene-ethyl acetate (97:3) provided compounds $2(5.5 \mathrm{mg})$ and 3 (7.0 mg).

Properties of isolated compounds. Glut-5(6)en-3-one (1): white crystals; mp 207-210 ${ }^{\circ} \mathrm{C}$; ${ }^{1} \mathrm{H}$ NMR (400 MHz, $\left.\mathrm{CDCl}_{3}\right): \delta 5.61(1 \mathrm{H}, \mathrm{m}, \mathrm{H}-6), 1.17$ (3H, s, Me-24), 1.16 (3H, s, Me-23), 1.10 (3H, s, Me-
28), 1.03 (3H, s, Me-26), 0.96 (3H, s, Me-27), 0.93

(3H, s, Me-30), 0.89 (3H, s, Me-29), 0.75 (3H, s, Me25).

Glut-5(6)-en-3a-ol (2): white needles; mp 203 ${ }^{\circ} \mathrm{C} ;{ }^{1} \mathrm{H}$ NMR (400 MHz, $\left.\mathrm{CDCl}_{3}\right): \delta 5.64(1 \mathrm{H}, \mathrm{d}, J=$ $6.4 \mathrm{~Hz}, \mathrm{H}-6), 3.47$ (1H, t, J=2.8 Hz, H-3), 1.17 (3H, s, Me-23), 1.14 (3H, s, Me-28), 1.10 (3H, s, Me-29), 1.05 (3H, s, Me-27), 1.01 (3H, s, Me-24), 0.99 (3H, s, Me-26), 0.95 (3H, s, Me-30), 0.85 (3H, s, Me-25).

(22E)-7-Hydroxy-28-methylcholesta-4,22-dien-3-one (3): white amorphous powder; ${ }^{1} \mathrm{H}$ NMR $\left(400 \mathrm{MHz}, \mathrm{CDCl}_{3}\right): \delta 5.70(1 \mathrm{H}, \mathrm{bs}, \mathrm{H}-4), 5.20(1 \mathrm{H}$, dd, $J=15.0,8.5 \mathrm{~Hz}, \mathrm{H}-23), 5.06(1 \mathrm{H}, \mathrm{dd}, J=15.5,9.0$ Hz, H-22), 3.67 (1H, m, H-7), 1.33 (3H, s, Me-19), $1.27(3 \mathrm{H}, \mathrm{d}, J=6.7 \mathrm{~Hz}, \mathrm{Me}-21), 0.85(3 \mathrm{H}, \mathrm{d}, J=6.8$ $\mathrm{Hz}, \mathrm{Me}-26$ and Me-27), 0.84 (3H,s, Me-28), 0.70 $(3 \mathrm{H}, \mathrm{s}, \mathrm{Me}-18)$.

Biological studies. The cytotoxic, antimicrobial and free radical scavenging activities of the isolated compounds ( $\mathbf{1}$ and $\mathbf{2}$ ) were determined by following the established methods. ${ }^{6-11}$

\section{RESULTS AND DISCUSSION}

A total of 3 compounds (1-3) were isolated from a methanol extract of stem bark of $B$. stipularis by column chromatography, gel permeation chromatography and preparative TLC. The structures of the isolated compounds were primarily solved by high field NMR data analysis and comparison with published values.

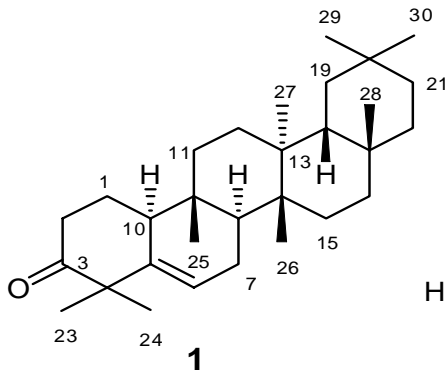

Compound 1 was characterized as glut-5(6)-en3-one by careful analysis of its high resolution ${ }^{1} \mathrm{H}$ NMR data comparison with reported values ${ }^{12}$ and further confirmed by melting point as well as co-TLC with an authentic glut-5(6)-en-3-one previously isolated in our laboratory. Therefore, the compound 1 was characterized as glut-5(6)-en-3-one, which is the first report from $B$. stipularis. 
Compound 2 melted at $203{ }^{\circ} \mathrm{C}$, which was identical to that reported for glut-5(6)-en-3-one. ${ }^{12}$ The ${ }^{1} \mathrm{H}$ NMR spectrum (400 $\mathrm{MHz}, \mathrm{CDCl}_{3}$ ) of compound 2 displayed an olefinic proton signal at $\delta$ $5.64(1 \mathrm{H}, \mathrm{d}, J=6.4 \mathrm{~Hz})$ and an oxymethine proton at $3.47(1 \mathrm{H}, \mathrm{t}, J=2.8 \mathrm{~Hz})$, which were assigned to $\mathrm{H}-6$ and $\mathrm{H}-3$, respectively of a triterpenoid type carbon skeleton. The oxymethine proton at $\delta 3.47$ was axial in configuration as confirmed by a triplet with $J$ value $2.8 \mathrm{~Hz}{ }^{13}$ The ${ }^{1} \mathrm{H}$ NMR spectrum also showed eight methyl group resonances as singlets at $\delta 0.85,0.95$, $0.99,1.01,1.05,1.10,1.14$ and 1.17. On the basis of the above spectral data, compound $\mathbf{2}$ was characterized as glut-5(6)-en-3 $\alpha$-ol. ${ }^{12}$ The identity of compound 2 as glut-5(6)-en-3 $\alpha$-ol was substantiated by comparison of its spectral data with published values as well as by co-TLC with authentic sample. This is the first report of isolation of glut-5(6)-en-3 $\alpha$ ol (2) from B. stipularis.

Table 1. Antimicrobial activity of compounds 1 and 2 at $50 \mu \mathrm{g} /$ disc isolated from B. stipularis

\begin{tabular}{|c|c|c|c|}
\hline \multirow[t]{2}{*}{ Test bacteria and fungi } & \multicolumn{3}{|c|}{ Diameter of zone of inhibition (mm) } \\
\hline & $\begin{array}{l}\text { Compound } 1 \\
(50 \mu \mathrm{g} / \mathrm{disc})\end{array}$ & $\begin{array}{r}\text { Compound } 2 \\
\mu \mathrm{g} / \mathrm{disc})\end{array}$ & Kanamycin $(30 \mu \mathrm{g} / \mathrm{disc})$ \\
\hline \multicolumn{4}{|l|}{ Gram positive bacteria } \\
\hline Bacillus cereus & $19.0 \pm 0.60$ & $16.1 \pm 0.66$ & 35 \\
\hline B. megaterium & $18.4 \pm 0.50$ & $16.9 \pm 0.91$ & 35 \\
\hline B. subtilis & $17.5 \pm 0.87$ & $16.3 \pm 1.05$ & 36 \\
\hline Staphylococcus aereus & $17.8 \pm 0.40$ & $18.2 \pm 0.89$ & 32 \\
\hline Sarcina lutea & $21.6 \pm 0.87$ & $20.7 \pm 1.22$ & 27 \\
\hline \multicolumn{4}{|l|}{ Gram negative bacteria } \\
\hline Escherichia coli & $22.7 \pm 0.65$ & $18.8 \pm 0.42$ & 25 \\
\hline Pseudomonas aeruginosa & $17.9 \pm 0.76$ & $18.4 \pm 0.76$ & 20 \\
\hline Salmonella paratyphi & $20.1 \pm 0.65$ & $18.4 \pm 0.76$ & 27 \\
\hline S. typhi & $22.1 \pm 0.65$ & $20.6 \pm 0.86$ & 22 \\
\hline Shigella boydii & $20.2 \pm 1.29$ & $18.1 \pm 0.86$ & 27 \\
\hline S. dysenteriae & $21.2 \pm 0.36$ & $19.2 \pm 0.66$ & 25 \\
\hline Vibrio mimicus & $21.3 \pm 0.91$ & $16.9 \pm 0.61$ & 25 \\
\hline V. parahemolyticus & $20.7 \pm 0.60$ & $18.9 \pm 0.59$ & 20 \\
\hline Fungi & & & Griseofulvin $(20 \mu \mathrm{g} / \mathrm{disc})$ \\
\hline Aspergillus niger & $19.1 \pm 0.35$ & $18.2 \pm 0.59$ & 20 \\
\hline Candida albicans & $18.5 \pm 0.60$ & $20.8 \pm 0.45$ & 18 \\
\hline Saccharomyces cerevisiae & $18.2 \pm 0.31$ & $20.2 \pm 0.83$ & 19 \\
\hline
\end{tabular}

The ${ }^{1} \mathrm{H}$ NMR spectrum of the compound $\mathbf{3}$ exhibited resonances at $\delta 0.70(3 \mathrm{H}, \mathrm{s}), 0.85(6 \mathrm{H}, \mathrm{d}$, $J=6.8 \mathrm{~Hz}$, overlapped), $1.27(3 \mathrm{H}, \mathrm{d}, J=6.7 \mathrm{~Hz})$ and $1.30(3 \mathrm{H}, \mathrm{s})$ attributable to the methyl groups at $\mathrm{C}-18$, C-26/27, C-21 and C-19, respectively in a cholestane type carbon skeleton. ${ }^{14}$ In the ${ }^{1} \mathrm{H}$ NMR spectrum, the olefinic protons at $\mathrm{H}-22$ and $\mathrm{H}-23$ appeared as characteristic downfield signals at $\delta 5.20(1 \mathrm{H}, \mathrm{m})$ and $5.06(1 \mathrm{H}, \mathrm{m}) .{ }^{14}$ Another olefinic proton signal at $\delta$
$5.70(1 \mathrm{H}, \mathrm{bs})$ was attributed to the trisubstituted double bond conjugated with the ketone group located at C-3, and therefore, the trisubstituted double bond could be placed between at C-4 and C-5. ${ }^{15}$ The ${ }^{1} \mathrm{H}-\mathrm{NMR}$ spectrum further revealed signals for an oxymethine proton at $\delta 3.67(1 \mathrm{H}, \mathrm{m})$ and a tertiary methyl proton at $\delta 0.84$ indicating a hydroxyl group at C-7 and a methyl group at C-28, respectively. ${ }^{16}$ In the literature, it was revealed that if the hydroxyl 
group was situated to $\mathrm{C}-24$, the proton chemical shifts of C-24, C-22 and C-23 could move upfield to $\delta 3.77,5.49$ and 5.38, respectively which do not match with the resonances observed in the ${ }^{1} \mathrm{H}$ NMR spectrum of compound 3. On this basis as well as by comparison of ${ }^{1} \mathrm{H}$ NMR data with two steroidal ketones reported in the literatures, ${ }^{14,15}$ compound $\mathbf{3}$ was tentatively characterized as (22E)-7-hydroxy-28methylcholesta-4,22-dien-3-one. This is the first report of occurrence of compound $\mathbf{3}$ from any natural and synthetic sources. However, additional spectral data are required to confirm its structure.

Biological studies. In case of cytotoxicity screening by brine shrimp lethality bioassay, the $\mathrm{LC}_{50}$ and $\mathrm{LC}_{90}$ values of the isolated compounds $\mathbf{1}$ and $\mathbf{2}$ were obtained from the best-fit slope when the data was presented graphically. Compound 1 revealed promising $\mathrm{LC}_{50}$ and $\mathrm{LC}_{90}$ values of 7.64 and 101.16 $\mu \mathrm{g} / \mathrm{ml}$, respectively. On the other hand, compound 2 exhibited $8.53 \mu \mathrm{g} / \mathrm{ml}$ for $\mathrm{LC}_{50}$ and $218.27 \mu \mathrm{g} / \mathrm{ml}$ for $\mathrm{LC}_{90}$, when compared to the standard vincristine sulfate ( $\mathrm{LC}_{50}$ value $0.45 \mu \mathrm{g} / \mathrm{ml}$ ).

Compounds $\mathbf{1}$ and $\mathbf{2}$ were subjected to antimicrobial screening which also demonstrated moderate to strong activity with zones of inhibition ranging from 10 to $21 \mathrm{~mm}$ at a concentration of 50 $\mu \mathrm{g} / \mathrm{disc}$ against different Gram positive and Gram negative bacteria and fungal strains in comparison to standard kanamycin and griseofulvin, respectively (Table 1). The highest zone of inhibition $(22.7 \mathrm{~mm})$ was produced by compound $\mathbf{1}$ against E. coli. Compound $\mathbf{2}$ showed highest activity against $C$. albicans with zone size of $20.8 \mathrm{~mm}$.

In addition, compound $\mathbf{2}$ showed moderate free radical scavenging activity with the $\mathrm{IC}_{50}$ value being $12.6 \mu \mathrm{g} / \mathrm{ml}$ as compared to the standards, i.e. tertbutyl-1-hydroxytoluene (BHT, $\mathrm{IC}_{50}=24.35 \mu \mathrm{g} / \mathrm{ml}$ ) and ascorbic acid (ASA, $\mathrm{IC}_{50}=5.80 \mu \mathrm{g} / \mathrm{ml}$ ).

It has been reported that structurally related triterpenes and steroids showed moderate to strong cytotoxic, antimicrobial and free radical scavenging activities. ${ }^{16-18}$ Therefore, the bioactivities of compounds 1-3 are in accordance with the previous findings.

\section{CONCLUSION}

Fractionation and purification of the methanolic extract of stem bark of B. stipularis collected from Panchouri, District Khagrachhori, Bangladesh afforded three compounds which were identified as glut-5(6)-en-3-one (1), glut-5(6)-en-3 $\alpha$-ol (2), and (22E)-7-hydroxy-28-methylcholesta-4,22-dien-3-one (3). Compound 3 appears to be new, and compounds $\mathbf{1}$ and $\mathbf{2}$ are the first report of their isolation from $B$. stipularis. Like other triterpenoids, compound $\mathbf{1}$ showed promising cytotoxic activity and compounds $\mathbf{1}$ and $\mathbf{2}$ demonstrated moderate to strong antibacterial activity against some Gram positive and Gram negative bacteria. They also showed good antifungal activity against a number of fungal strains.

\section{ACKNOWLEDGEMENTS}

The authors wish to thank Dr. Bushra Khan, Senior Scientific Officer, Bangladesh National Herbarium, Ministry of Environment and Forest, Dhaka, Bangladesh for identifying the plants and also Biomedical Research Centre, University of Dhaka, Bangladesh and Department of Pharmacy, State University of Bangladesh, Dhaka, Bangladesh for providing laboratory facilities to carry out some of the experiments.

\section{REFERENCES}

1. Kirtikar, K.R. and Basu, B.D.1980. Indian medicinal plants. Edn 2, Vol. III, Lalit Mohan Basu, Allahabad, India, pp. 2214-2215.

2. Nasir, U.S. 2006. Traditional uses of ethnomedical plants of the Chittagong Hill Tracts, 1st edition, Bangladesh National Herbarium, pp. 407-408.

3. Krishnan, K.S. 1992. The useful plants of India, reprinted, publications and information directorate, CSIR, New Delhi, India, pp. 86-87.

4. Anjum, A., Haque, M.R., Rahman, M.S., Hasan, C.M., Haque, M.E. and Rashid, M.A. 2011. In vitro antibacterial, antifungal and cytotoxic activity of three Bangladeshi Bridelia species. Int. Res. Pharm. Pharmacol. 1, 149-154.

5. Anjum, A., Sikder, M.A., Haque, M.R., Hasan, C.M. and Rashid, M.A. 2013. In vitro antioxidant and thrombolytic activities of Bridelia species growing in Bangladesh. J. Sci. Res. 5, 343-351. 
6. McLaughin, J.L., Rogers, L.L. and Anderson, J.E. 1998. The use of biological assays to evaluate botanicals. Drug Inform. J. 32, 513-524.

7. Meyer, B.N., Ferringni, N.R., Putnam, J. E., Jacobsen, L.B., Nichols, D.E. and McLaughin, J.L. 1982. Brine shrimp: a convenient general bioassay for active plant constituents. Planta Med. 45, 31-32.

8. Bauer, A.W., Kirby, W.M., Sherries, J.C., Turck, M. 1966. Antibiotic susceptibility testing by a standardized single disc method. Am. J. Clin. Path. 45, 493-496.

9. Sultan, M.Z., Jeon, Y.-M. and Moon, S.-S. 2008a. Labdanetype diterpenes active against acne from pine cones (Pinus densiflora). Planta Med. 74, 449-452.

10. Sultan, M.Z., Park, K., Lee, S.Y., Park, J.K., Varughese, T. and Moon, S.S. 2008b. Novel oxidized derivatives of antifungal pyrrolnitrin from the bacterium Burkholderia cepacia K87. J. Antibiot. 61, 420-425.

11. Brand-Williams, W., Cuvelier, M.E. and Berset, C. 1995. Use of a free radical method to evaluate antioxidant activity. Lebensm. Wiss. Technol. 28, 25.

12. Shazid, M.S., Hossain, M.K., Haque, M.R., Chowdhury, A.A., Kaisar, M.A., Hasan, C.M. and Rashid, M.A. 2012. Chemical and biological studies of Kalanchoe pinnata (Lam.) growing in Bangladesh. Asian Pacific J. Trop. Biomed. S1317-S1322.
13. Xue-jing, L., Xie, Z., Wang, Y.H., Yan, Y.M., Pei, G. and Zhou, X.J. 2012. Study on the chemical constituents from the leaves of Hydnocarpus haimanensis. Zhongyaocai 35, 17821784 .

14. Aiello, A., Ciminiello, P., Fattorusso, E. and Magno, S. 1988. Three new 7-keto sterols from the Mediterranean sponge. Steroids 52, 533-542.

15. Mellado, G.G., Zubia, E., Ortega, M.J. and Lopez-Gonzalez, P.J. 2004. New polyoxygenated steroids from the Antartic octoral Dasystenella acanthia. Steroids 69, 291-299.

16. Notaro, G., Piccialli, V. and Sica, D. 1992. New steroidal hydroxyketones and closely related diols from the marine sponge Clonia copiosa. J. Nat. Prod. 55, 1588-1594.

17. Sanan S. and Pharkphoom P. 2005. A terpenoid and two steroids from the flowers of Mammea siamensis. Songklanakarin J. Sci. Technol. 27 (Suppl. 2), 555-561.

18. Kontiza, I., Abatis,D., Malakate, K., Vagias, C., and Roussis, V. 2006. 3-Keto steroids from the marine organisms Dendrophyllia cornigera and Cymodocea nodosa. Steroids 71, 177-181. 